\title{
Imageologia da relação do diâmetro da íris com a padronização do tamanho da face para sobreposição de fotografias
}

\section{Study of the diameter of the iris to created a pattern of the size of the face in photography for superimpositio}

\author{
Maria Aurélia Varella
}

\begin{abstract}
Varella, M. A. Imageologia da relação do diâmetro da íris com a padronização do tamanho da face para sobreposição de fotografias [Resumo]. Saúde, Ética \& Justiça, São Paulo. 2003;8(1/2):59.
\end{abstract}

\begin{abstract}
RESUMO: Neste trabalho constatou-se a possibilidade de criar um padrão para estabelecer o tamanho da imagem da face tomando-se como base o diâmetro da íris e as variações das proporções faciais nas diferentes posições da cabeça: flexão, extensão, rotação e flexão lateral, nos ângulos de $5^{\circ}, 10^{\circ}$ e $15^{\circ}$. Medidas foram feitas em 51 indivíduos e suas fotografias. Os resultados mostraram que o diâmetro da íris não varia com idade, sexo ou cor da pele e tampouco com a posição da cabeça, desde que o indivíduo olhe para a câmera. Concluiu-se que a íris é um elemento confiável para padrão de tamanho de imagem com finalidade de sobreposição e que determinadas posições da cabeça alteram proporções faciais.
\end{abstract}

DESCRITORES: Íris/anatomia e histologia. Face/anatomia e histologia. Antropologia forense/métodos. Fotografia/métodos. Medicina legal.

\begin{abstract}
Varella, M. A. Study of the diameter of the iris to created a pattern of the size of the face in photography for superimpositio [Abstract]. Saúde, Ética \& Justiça, São Paulo. 2003;8(1/2):59.

ABSTRACT: The purpose of this study was to verify the possibility of creating a pattern to establish the face's size, having as basis, the iris diameter and the variations of facial proportions in different head positions: flexion, extension, rotation, lateral flexion, in three different angulations of $5^{\circ}, 10^{\circ}$ and $15^{\circ}$. The measures were taken in 51 individuals and their pictures. Results showed that the iris diameter doesn't vary according to age, sex or race. As well it does not vary with the change of head position, if the person is looking straightly to the camera. It was concluded that the iris diameter is a reliable element to be used as an image size pattern for superimposition and certain head positions alter facial proportions.
\end{abstract}

KEY WORDS: Iris/anatomy \& histology. Face/anatomy \& histology. Forensic anthropology/methods. Photography/methods. Forensic medicine.

Tese apresenta à Faculdade de Medicina da Universidade de São Paulo, defesa em 2002.

Orientador: Daniel Romero Muñoz.

Endereço para correspondência: e-mail: maurelia @terra.com.br 